\title{
Interdisciplinary Research in Education
}

Volume 4, Issue 2, 2020: 215-230

DOI: https://doi.org/10.3126/ire.v4i2.27937

\section{नेपालमा बोलिने भाषाहरूको परिचय}

\author{
कुश्मिला आचार्य \\ नेपाली शिक्षा, त्रि.वि., कीर्तिपुर \\ E-mail: acharyakushmila@gmail.com
}

\begin{abstract}
लेखसार
प्रस्तुत लेख विश्वमा बोलिने भारोपेली, द्रविड, मलय पोलिनेसियन, ककेसियाली, अष्ट्रक, जापानीकोरियाली, युराल-अल्ताइली, अमेरिकाली, चिनीयाँ-तिब्बती र अफ्रिकाली भाषापरिवार मधये नेपालमा बोलिने भारोपेली, द्रविड, अष्ट्रिक र चिनीयाँ-तिब्बतीभाषाहरूको अध्ययनमा केन्द्रित छ। संसारमा धेरै भाषा परिवारका भाषाहरू बोल्ने मत पाइए पनि अधिक भाषाशास्त्रीहरूको मतमा संसारमा 90 वटा भाषापरिवारका भाषाहरू बोलिन्छन । जसमध्ये नेपालको राष्ट्रिय जनगणना २०६६ अनुसार नेपालमा $\gamma$ वटा भाषापरिवार र एउटा एकल परिवारको भाषा गरी 9 २३ वटा भाषाहरू बोलिन्छन्। प्रस्तुत लेखमा नेपालमा बोलिने भाषा परिवारका भाषाहरूको २०४६ र २०६५ को जनगणना अनुसार तुलनात्मक अध्ययन गरिएको छ। यसमा उक्त १२३ भाषामध्ये चारवटा भाषामध्ये चारवटा भाषा परिवार र एउटा एकल भाषा परिवार अन्तर्गत वक्ता सड़ख्याको वाहुल्यता भएका जम्मा ३० वटा भाषाको परिचय, प्रयोग क्षेत्र, वक्तासड्ख्या र प्रतिशतका वारेमा चर्चा गरिएको छ। यसका लागि राष्ट्रिय जनगणना २०६५ का तथ्याङ्कलाई मुख्य आधार मानिएको छ। यस लेखले अब हुने नेपालको बाह्रों राष्ट्रिय जनगणना २०७५ मा भाषिक गणनालाई व्यवस्थित बनाउनुपर्ने कुराप्रति सड़केत पनि गरेको छ।
\end{abstract}

मुख्य शब्दावली : भाषा, भाषा परिवार, भारोपेली, भोटवर्मेली, आग्नेली, द्रविडेली, भाषिक जीवन्तता, मातृभाषा, जनगणना।

\section{उद्देश्य}

प्रस्तुत अनुसन्धानमूलक लेखको उद्देश्य नेपालमा बोलिने प्रमुख भाषाका विश्लेषणत्मक अध्ययन गर्नु रहेको छ। विशिष्टीकृत रूपमा नेपालमा १० वर्षको अन्तरालमा भाषामा भएको परिवर्तनको तुलना गर्नु, नेपालमा बोलिने भाषा परिवारको परिचय दिनु, नेपालमा बोलिने भाषा परिवारका प्रमुख भाषाहरूको परिचय दिनु, प्रयोग, क्षेत्र र वक्ता सड्ख्याको तुलनात्मक अध्ययन गरेर निष्कर्ष निकाल्नु यस लेखका उद्देश्यहरू रहेका छन् । 


\section{अध्ययनविधि}

प्रस्तुत अनुसन्वेय विषय गुणात्मक विधिमा आधारित छ। सामाग्री सड्कलनको प्राथमिक र द्वितीयक स्रोत मध्ये द्वितीयक स्रोतका सामग्रीको उपयोग गरिएको छ। पुस्तकालयको प्रयोग गरी विभिन्न सन्दर्भ पुस्तक, जर्नल, अनुसन्धानमूलक लेख, पत्रपत्रिका आदिको उपयोग गरी वर्णनात्मक, विश्लेषणात्मक र तुलनात्मक रूपमा विश्लेष्य विषयको निष्कर्ष निकालिएको छ।

\section{सैद्धान्तिक अवधारणा र विश्लेषणको ढाँचा}

प्रस्तुत अध्ययनको सैद्धान्तिक पर्याधार भाषा परिवार र भाषिक जनगणनाको सिद्धान्त हो । बन्धु (२०७३) ले नेपालमा बोलिने भारोपेली, भोटबर्मेली, आग्नेसियाली र द्रविड भाषा परिवारका भाषाहरू र एकल भाषा परिवारको रूपमा कुसुन्डालाई विश्लेषण गरेका छन्। यी भाषा परिवारका सिद्धान्त, स्थिति, सड्ख्या, अवस्थालाई प्रस्तुत लेखले विश्लेषणको आधार बनाएको छ। केन्द्रीय तथ्याङ्क विभाग (२०४९) को नेपालको राष्ट्रिय जनगणना २०४६ र केन्द्रीय तथ्याड्क विभाग (२०६९) को नेपालको राष्ट्रिय जनगणना २०६६ मा प्रस्तुत गरिएका भाषा परिवारका सड्ख्या र अवस्थालाई तुलनात्मक विश्लेषण गरिएको छ, भने यी जनगणना मध्ये राष्ट्रिय जनगणना २०६६ ले तथ्याङ्कमा दिएका भाषाहरूलाई वक्ता सड्ख्याको आधारमा कमिक रूपमा विश्लेषण गरिएको छ।

\section{विषय प्रवेश}

नेपाल भौगोलिक रूपमा सानो देश भए तापनि सामाजिक, सांस्कृतिक र भाषिक दृष्टिले अत्यन्त समृद्ध छ। नेपाल विविध जातजाति, संस्कृति र भाषाभाषीको सड़मस्थल हो। भाषावैज्ञानिक दृष्टिबाट सर्वेक्षण हुन बाँकी भए पनि नेपालमा मुख्य रूपमा भारोपेली, चिनीयाँ-तिब्बती, द्रविड र आग्नेली परिवारका भाषाहरू बोलिएको पाइन्छ (ओभा, २०६७, प्. ४०६)। नेपालमा विश्वका चर्चित भाषापरिवारका भाषामध्ये ४ वटा भाषापरिवारका भाषा र एकल परिवारको एउटा भाषा बोलिन्छन् ।

भारोपेली विश्वको सबैभन्दा धेरै मानिसहरूले बोल्ने भाषाका रूपमा रहेको छ। नेपालमा पनि सबैभन्दा बढी वक्ता यसै भाषा परिवारको रहेको कुरा राष्ट्रिय जनगणना २०६५ को तथ्याङ्कबाट स्पष्ट हुन्छ। भोटबर्मेली, आग्नेली र द्रविड भाषा परिवारका वक्ताहरू विश्वका साथै नेपालमा पनि उल्लेख्य रूपमा रहेका पाइन्छन् । नेपालमा बोलिने कुसुन्डा भाषाको अध्ययन गर्दा भाषावैज्ञानिकहरूले उपर्युक्त चार भाषापरिवारको भन्दा भिन्न अभिलक्षण यसमा रहेको दृष्टिकोण राखेको पाइन्छ। यसरी नेपालमा $y$ भाषापरिवारका भाषाका वक्तारहेका छन् ।

नेपालमा भाषाको सड्ख्या बढ़दो ऋममा रहेको कुरा पछिल्ला जनगणनाको तथ्याङ्कबाट स्पष्ट हुन्छ। भाषाको सड्ख्या बढ़नुमा आफ्नो भाषाप्रति भाषिक बफादारिता बढ़नु, आफ्नो पहिचान खोज्नु, शिक्षाको स्तर बढ़नु, भाषिक रूपमा सड्गठठित हुनु, राज्यले भाषाको संरक्षण, संबर्धन र विकासमा अग्रसरता देखाउनु आदि रहेका छन्। राष्ट्रिय जनगणना २०४६ र २०६६ अनुसार नेपालका भाषाहरूको पारिवारिक अवस्थाको तुलनात्मक स्थिति निम्न अनुसार छ : 
नेपालमा बोलिने भाषाहर्को परिचय/217

तालिका १ : नेपालका भाषाहरूको तुलनात्मक पारिवारिक वर्गीकरण २०४६ र २०६६

\begin{tabular}{|c|c|c|c|c|c|}
\hline \multirow{2}{*}{ ऋ.सं } & \multirow{2}{*}{ भाषा परिवार } & \multicolumn{2}{|c|}{ राष्ट्रिय जनगणना २०४६ } & \multicolumn{2}{|c|}{ राष्ट्रिय जनगणना २०६६ } \\
\hline & & भाषा सड्ख्या & वक्ता प्रतिशत & भाषा सड़ख्या & वक्ता प्रतिशत \\
\hline 9. & भारोपेली & ३० & ५०. २६ & $8 \rho$ & दर. 99 \\
\hline २. & चीन तिब्बती & $y=$ & २६.६६ & ७० & १७.३१ \\
\hline ३. & आग्नेसियाली & २ & 0.99 & 2 & 0.99 \\
\hline$\gamma$. & द्रविड & 9 & $0.9 ३$ & 9 & $0.9 ३$ \\
\hline$y$. & एकल भाषा & 9 & ०.००(६৩ जना) & 9 & ०.००(२६ जना) \\
\hline$\xi$. & उल्लेख नभएको & - & $0 . ৩ 8$ & - & 0.95 \\
\hline$\vartheta$. & अन्य & - & - & - & 0.00 \\
\hline कुल & & $\rho 2$ & 900 & १२३ & 900 \\
\hline
\end{tabular}

स्रोत : केन्द्रीय तथ्याड्क विभाग, राष्ट्रिय जनगणना, २०४६ र २०६६

माथिको तालिका 9 मा राष्ट्रिय जनगणना २०४६ द मा भारोपेली परिवारको भाषाको सड्ख्या ३० रहेकोमा २०६६ मा १९ वटाले थपिएर ४९ वटा पुगेको छ। त्यसैगरी चीन तिब्बती भाषाको सड्ख्या २०४६ मा पू द रेकोमा १२ वटाले थपिएर ७० पुगेको छ। यसैगरी वक्ता सड्ख्या पनि बढेको छ। आग्नेसियाली र द्रविड भाषा परिवारका भाषा सड्ख्या २०४६ र २०६६ मा २/२ र वक्ता सड्ख्याको प्रतिशत पनि समान रहेको छ। २०४६ र २०६६ मा एकल भाषा परिवारको सड्ख्या १/१ रहेको र २०४६ मा ६७ जना वक्ता रहेकोमा २०६६ मा प९ जनाले घटेर २६ जना रहेको देखिन्छ। उल्लेख नभएको भाषा परिवारको सड्ख्या २०४६ र २०६६ मा देखिंदैन भने २०४६ मा ०.७४ प्रतिशत र २०६६ मा ०.१६ प्रतिशत वक्ता सड्ख्याको भाषा उल्लेख नभएको देखिन्छ। २०५ द मा अन्य भाषा परिवारको भाषा सड्ख्या र वक्ता प्रतिशत छैन भने २०६६ मा ०.०७ प्रतिशत वक्ताको स्पष्ट भाषा नभएको देखिएको छ।

यसरी वि.सं. २०४ द मा ९२ रहेको नेपालको भाषा वि.सं. २०६६ मा ३१ वटाले बढेर १२३ पुगेको देखिन्छ। नेपालको विभिन्न जनगणनाको तथ्याङ्क हेर्दा भाषासम्बन्धी तथ्याङ्क फरक फरक देखिन्छ। यसो हुनुमा भाषाको व्यवस्थित, वैज्ञानिक गणना हुन नसक्नु, पूर्ण भाषावैज्ञानिक तथा समाजभाषावैज्ञानिक रूपमा भाषाको अध्ययन नहुनु आदिले यस्तो समस्या आएको भनेर विश्लेषण गर्न सकिन्छ । यसतर्फ सम्बन्धित निकायले विशेष ध्यान दिनु आवश्यक देखिन्छ।

भारोपेली र भोटबर्मेली भाषा परिवारमा भाषा सड्ख्या वि. सं. २०४६ भन्दा वि.सं. २०६६ मा बढ़ी देखिनुका कारणहरू राजनीतिक रूपमा क्षेत्र विभाजन गर्नु, एउटै भाषाका विविध भेदलाई छुट्याउनु, भाषिकालाई पनि भाषाको मान्यता दिनु, वैज्ञानिक भाषिक जनगणना हुन नसक्नु, गणकहरू तालिम प्राप्त नहुनु, भाषिक चेतनाका कारण स्व-पहिचानको लागि आफ्नो भाषाको संरक्षणमा व्यक्ति, समुदाय, संस्था लाग्नु आदि कारणहरू रहेका कुरा विभिन्न भाषाविद्हरूले उल्लेख गरेका छन्। 


\section{क) भारोपेली भाषापरिवार}

विश्वमा नै सबैभन्दा बढ़ी वक्ता भएको यस परिवारका भाषहरूको वक्ताको सड्ख्या नेपालमा पनि सबैभन्दा धेरै रहेको छ। राष्ट्र भाषा नेपाली पनि भारोपेली परिवारअन्तर्गतको नै भाषा हो (गौतम र चौलागाई, २०७० पृ. ३७९)। नेपाली, मैथिली जस्ता समृद्ध साहित्य भएको भाषाहरू यसै भाषापरिवार अन्तर्गत पर्दछ् । नेपालको राष्ट्रिय जनगणना २०४६ र २०६६ अनुसार भारोपेली भाषापरिवारमा पर्ने नेपालका भाषाहरूको तुलनात्मक अवस्थानिम्न तालिका प्रस्तुत गरिएको छ :

तालिका २ : नेपालमा बोलिने भारोपेली परिवारका भाषाहरूको तुलना २०४६ र २०६५

\begin{tabular}{|c|c|c|c|c|c|c|c|}
\hline $\begin{array}{l}\text { क. } \\
\text { सं. }\end{array}$ & $\begin{array}{l}\text { भाषा } \\
\text { परिवार }\end{array}$ & राष्ट्रिय जनग & ना २०पू & & $\begin{array}{r}\text { राष्ट्रिय } \\
\text { २० }\end{array}$ & गणणना & \\
\hline & भारोपेली & भाषा & $\begin{array}{l}\text { वक्ता } \\
\text { प्रतिशत }\end{array}$ & वक्ता सड्ख्या & भाषा & $\begin{array}{l}\text { वक्ता } \\
\text { प्रतिशत }\end{array}$ & वक्ता सड्ख्या \\
\hline 9. & & नेपाली & $\gamma \zeta . \xi$ & १९०४३२Уू & नेपाली & $\gamma \curlyvee . \xi$ & ११६२६९४३ \\
\hline २. & & मैथिली & १२.३० & २७९७४ दर & मैथिली & 99.0 & ३०९ २૫३० \\
\hline ३. & & भोजपुरी & ७. $2 \xi$ & १७१२४३६ & भोजपुरी & $\xi . \vartheta$ & 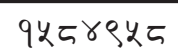 \\
\hline$\gamma$. & & थारू & y.६द & १३३१џ૪६ & थारू & 4.5 & २५२९ ऽ७Y \\
\hline$y$. & & बज्जिका & 9.04 & ২३७९ ४ & बज्जिका & 2.99 & ৩९३४৭६ \\
\hline$\xi$ & & - & - & - & डोटेली & 2.90 & ৩૬৩๘২৩ \\
\hline$\vartheta$. & & उर्द्द & $0 . \vartheta ७$ & ৭৩૪๘૪০ & उर्द्द & २.६ & $\xi ९ 94 ช \xi$ \\
\hline द. & & अवधी & २. २७ & पू६०७૪૪ & अवधी & 9.9 & y०१७पर \\
\hline$\rho$. & & - & - & - & बैतडेली & १.०३ & २७२५२४ \\
\hline 90. & & - & - & - & आछामी & 0.28 & ৭૪২७ム৩ \\
\hline 99. & & राजबंशी & 0.40 & १२९न२९ & राजबंशी & 0.5 & १२२२१४ \\
\hline १२. & & हिन्दी & $0 . \curlyvee ७$ & १०४४७६ू & हिन्दी & $0 . ३$ & ७७४६६९ \\
\hline q३. & & - & - & - & बभाडी & $0.2 \xi$ & ६७४ ६१ \\
\hline 98. & & दनुवार & 0.98 & ३१६४९ & दनुवार & 0.2 & ४Уद२१ \\
\hline $9 y$. & & मगही & 0.9 & ३० & मगही & $0.9 ३$ & ३५६१૪ \\
\hline १६. & & $\begin{array}{l}\text { राजस्थानी / } \\
\text { माडबारी }\end{array}$ & 0.90 & २२६३७ & राजस्थानी & 0.90 & २५३९૪ \\
\hline$q \vartheta$. & & माभी & 0.90 & २१६४१ & माकी & 0.05 & २४४२२ \\
\hline 9 द. & & $\begin{array}{l}\text { बाड़्ला / } \\
\text { बड़्ग्याली }\end{array}$ & 0.90 & २३६०२ & $\begin{array}{l}\text { बाड्ला / } \\
\text { बड़ग्याली }\end{array}$ & 0.05 & २१०६१ \\
\hline 99. & & - & - & - & ताजपुरिया & 0.06 & 9ББ99 \\
\hline 20. & & अड़गिका & 0.00 & 9पद९? & अड़गिका & $0.0 ७$ & $9 z y y z$ \\
\hline २१. & & कुमाल & O.০३ & 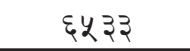 & कुमाल & 0.08 & १२२२२ \\
\hline २२. & & दराई & 0.08 & 90290 & दराई & 0.90 & ৭৭६७७ \\
\hline
\end{tabular}


नेपालमा बोलिने भाषाहर्को परिचय/219

\begin{tabular}{|c|c|c|c|c|c|c|}
\hline २३. & - & - & - & बाजरेली & 0.08 & q०७০४ \\
\hline २४. & बोटे & 0.09 & २६२३ & बोटे & $0.0 ३$ & こ७६६ \\
\hline $2 y$. & - & & - & दार्चुलेली & 0.02 & प९२द \\
\hline २६. & $\begin{array}{l}\text { साङ्केतिक } \\
\text { भाषा }\end{array}$ & O.०३ & y ७૪३ & $\begin{array}{c}\text { साङ्केतिक } \\
\text { भाषा }\end{array}$ & 0.02 & ૪૪७६ \\
\hline २७. & - & - & - & गन्गाइ & 0.09 & ३६१२ \\
\hline २६. & - & - & - & दैलेखी & 0.09 & ३१०२ \\
\hline 29. & अड़ग्र्रेजी & 0.00 & १०३७ & अड़ग्रेजी & 0.09 & २०३२ \\
\hline ३०. & - & - & - & खस & 0.09 & q৩૪৩ \\
\hline ३१. & संस्कृत & 0.00 & Б२३ & संस्कृत & 0.09 & १६६९ \\
\hline ३२. & किसान & 0.00 & $\gamma \sqsubseteq \rho$ & किसान & 0.00 & ৭৭৩দ \\
\hline ३३. & चुरौटी & 0.00 & ૪О૬ & मुसल्मान & 0.00 & q०७y \\
\hline ३४. & हरियान्वी & 0.00 & ३३ & हरियान्वी & 0.00 & Б59 \\
\hline ३2. & - & - & - & जुम्ली & 0.00 & 529 \\
\hline ३६. & पन्जाबी & 0.09 & १९६प & पन्जाबी & 0.00 & दOद \\
\hline ३७. & उडिया & 0.00 & 949 & उडिया & 0.00 & $y=\gamma$ \\
\hline ३६. & - & - & - & सोनाहा & 0.00 & y०९ \\
\hline ३९. & सिन्धी & 0.00 & ७२ & सिन्धी & 0.00 & 295 \\
\hline ૪૦. & - & - & - & डडेलधुरी & 0.00 & 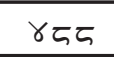 \\
\hline 89. & आसामी & 0.00 & ३ & आसामी & 0.00 & ૪६७ \\
\hline ४२. & - & - & - & माल्पाँडे & 0.00 & २४७ \\
\hline ૪३. & कुर्माली & 0.00 & $9 ३$ & कर्माली & 0.00 & २२७ \\
\hline$\gamma \gamma$. & सधानी & 0.00 & 2 & सधानी & 0.00 & 922 \\
\hline$\gamma y$. & - & - & - & गढवाली & 0.00 & ३६ \\
\hline ૪६. & - & & - & $\begin{array}{l}\text { फ्रेन्च / } \\
\text { फ्रान्सेली }\end{array}$ & 0.00 & ३४ \\
\hline$\gamma \vartheta$. & - & & - & रसियाली & 0.00 & 90 \\
\hline$\gamma \zeta$. & - & & - & स्पेनेली & 0.00 & $9 \xi$ \\
\hline$\gamma \rho$. & - & & - & अरबी & 0.00 & ᄃ \\
\hline
\end{tabular}

स्रोत : केन्द्रीय तथ्याङ्क विभाग, राष्ट्रिय जनगणना, २०४६ र २०६६

तालिका नं. २ मा नेपालको राष्ट्रिय जनगणना २०४६ र २०६६ अनुसार भारोपेली भाषाका वक्ताहरू दिइएको छ। भारोपेली भाषा परिवारमा राष्ट्रिय जनगणना २०४६ मा ३० वटा भाषाहरू रहेकोमा राष्ट्रिय जनगणना २०६६ मा १९ वटा भाषा थपिएर ४९ भाषा भएको देखिन्छ। डोटेली, बैतडेली, अछामी, बभाडी, ताजपुरिया, बाजुरेली, दार्चुलेली, गन्गाई, दैलेखी, खस, जुम्ली, सोनहा, डडेलधुरी, मालपाँडे, गढवाली, फ्रान्सेली, रसियाली, स्पेनेली र अरबी भाषाहरू २०६६ मा थप भएका भारोपेली भाषा परिवारका भाषाहरू हुन्। भारोपेली भाषाका मुख्य भाषाहरूलाई निम्नानुसार उल्लेख गरिएको छ : 


\section{नेपाली भाषा}

नेपालमा बोलिने भाषाहरूमा सबैभन्दा समृद्ध भाषा नेपाली हो। यो भारोपेली परिवारको संस्कृत, प्राकृत र अपभ्रंश हुँदे विकसित भएको भाषा हो (गौतम र चौलागाईं, २०७०, पृ. ३७९)। नेपालमा नेपाली भाषाले राष्ट्रभाषा, साभा सम्पर्क भाषा, शिक्षा, सन्चार, प्रशासन तथा प्रकाशनको माध्यम भाषा बन्ने सौभाग्य पाएको छ। मेचीदेखि महाकालीसम्म नेपालमा मातृभाषा र दोस्रो भाषाका रूपमा नेपाली प्रयोग गरिन्छ भने यसका साथै भारतका विभिन्न ठाउँहरू, भूटान, बर्मा आदि देशमा समेत नेपाली भाषी वक्ताहरू पाइन्छन्। करिब १००० वर्ष पुरानो इतिहास बोकेको नेपाली भाषा ज्ञान, विज्ञान, कला, धर्म सांस्कृतिक दृष्टिले समृद्ध छ। राष्ट्रिय जनगणना, २०६५ अनुसार यसको वक्ता सड्ख्या ४४.६ प्रतिशत रहेको छ।

\section{मैथिली भाषा}

नेपाली भाषापछि दोस्रो स्थानमा रहेको भाषा मैथिली हो । संस्कृत भाषाको मागधी प्राकृत भेदबाट विकसित मैथिली मिथिला क्षेत्रमा बोलिने भएकाले यस भाषाको नाम मैथिली नामाकरण गरिएको हो। यो भाषा नेपालका पूर्वी तराई रौतहटको गौरदेखि सर्लाही, महोत्तरी, धनुषा, सिरहा, सप्तरी, मोरङ, सुनसरी र भापासम्म बोलिन्छ (शर्मा र लुइटेल, २०६०, पृ. ३०४)। यस भाषामा साहित्यलेखन, पत्रिका प्रकाशन, रेडियो तथा टि.भि.मा समाचार तथा अन्य कार्यक्रम प्रसारण, फिल्म, टेलिफिल्म निर्माण जस्ता कार्यहरू भएका छन्। पहिले तिरहुता लिपिमा लेखिने मैथिली अहिले देवनागरी लिपिमा नै लेखिनेगरिएको छ। यस भाषालाई नेपालमा प्राथमिक तहदेखि उच्च शिक्षासम्म पढ़न पाउने व्यवस्था समेत रहेको छ। राष्ट्रिय जनगणना, २०६६ अनुसार यसको वक्ता सड्ख्या ११.७ प्रतिशत रहेको छ।

\section{भोजपुरी भाषा}

भोजपुरी भाषा पनि मागधी प्राकृतिक भाषाबाट विकसित भएको भाषा हो । भारतको प्राचीन नगर भोजपुरमा बोलिने भएकाले यस भाषाको नाम भोजपुरी रहन गएको हो। त्यसो त नेपालमा पनि भोजपुर जिल्ला छ तर नेपालको भोजपुर जिल्लासँग यस भाषाको कुनै सम्बन्ध देखिंदैन । नेपालभन्दा भारतमा बढी बोलिने यो भाषा नेपालका बारा, पर्सा, रौतहट, चितवन, रूपन्देही आदि जिल्लाहरूमा बोलिन्छ। पहिले कैथि लिपिमा लेखिने भोजपुरी भाषा हाल देवनागरी लिपिमा नै लेखिन्छ। प्राचीन साहित्य र लोक साहित्यमा भोजपुरी भाषा समृद्ध मानिन्छ। राष्ट्रिय जनगणना, २०६६ अनुसार यसको वक्ता सड्ख्या ६.७ प्रतिशत रहेको छ।

\section{थारु भाषा}

यो भाषा मागधी प्राकृताबाट विकसित भएको ठानिन्छ। मोरङ, सुनसरी, सप्तरी, चितवन, कपिलवस्तु, दाड, बाँके, बर्दिया, कैलाली र कज्चनपुरका तराई र भित्रीमदेश नै यस भाषाका वक्ताहरूको मूल थलो हो (ढकाल, २०६६, पृ. ३६२)। थारु जातिले प्रयोग गर्ने भएकाले यस भाषालाई थारु भाषा भनिन्छ। थारुहरू नेपालका प्राचीन जाति हुन् । अंशुवर्माको शिलालेखमा थारु शब्द प्रयोग गरिनुले यसको प्राचीनतालाई फल्काउँछ। थारु भाषा नेपालको तराईका जिल्लाहरू पूर्वदेखि पश्चिमसम्मका थारु समुदायमा यस भाषाको प्रयोग गरिन्छ। मैथिली, भोजपुरी, हिन्दी आदि भाषाहरूबाट प्रभावित थारु भाषामा ठाउँ अनुसार विविधता पाइन्छ। थारु भाषामा पुरानो साहित्यिक परम्परा नभए पनि अहिले यस भाषामा पत्रिका प्रकाशन गर्ने, 
नेपालमा बोलिने भाषाहर्को परिचय/ 221

शब्दकोश तथा व्याकरण लेख्ने कार्यका सुरुवात भइरहेको छ। राष्ट्रिय जनगणना, २०६६ अनुसार यसको वक्ता सड्ख्या 4.5 प्रतिशत रहेको छ।

\section{अवधि भाषा}

यो भाषा भारतको उत्तर प्रदेशको अवध क्षेत्रमा बोलिने भएकाले यसको नाम अवधि भएको हो। यो भाषा नेपालको नवलपरासी, रूपन्देही, कपिलवस्तु, बाँके, बर्दिया, कैलाली, कन्चनपुर जस्ता जिल्लामा बोलिन्छ (ढकाल, २०६६, पृ. ३६२)। अवधि भाषा पनि संस्कृतको अर्धमागधी प्राकृत भाषाबाट विकसित भएको भाषा हो। लोकसाहित्यको ठूलो भण्डार भएको अवधि भाषा पहिले स्वतन्त्र भाषाका रूपमा प्रतिष्ठित भए तापनि हाल यसलाई हिन्दी भाषाको क्षेत्रीय भेदका रूपमा पनि लिइन्छ। राष्ट्रिय जनगणना, २०६६ अनुसार यसको वक्ता सङ्ख्या १.९ प्रतिशत रहेको छ।

\section{उर्दू भाषा}

नेपालको तराईका जिल्लाहरूमा बोलिने उर्दू भाषीहरूको संख्या नेपालमा एकदमै न्यून छ। नेपालमा न्यून भए पनि भारत र पाकिस्तानमा यस भाषाले राष्ट्रभाषाको सम्मान पाएको छ। पाकिस्तानमा त प्रमुख राष्ट्रभाषा नै उर्दू हो। साहित्यिक दृष्टिले उर्दू भाषा निकै सम्पन्न छ। यो भाषा अरबी लिपिमा लेखिन्छ (गौतम र चौलागाई, २०७०, पृ. ३७३)। नेपालमा राष्ट्रिय जनगणना २०६६ अनुसार २.६ प्रतिशत जनसंख्याले मातृभाषाको रूपमा यस भाषाको प्रयोग गर्ने गरेको तथ्याङ्क छ।

\section{राजबंशी भाषा/ताजपुरिया}

वि.सं. २०६६ को जनगणना अनुसार ०.६ प्रतिशतले मातृभाषाको रूपमा प्रंयोग गर्ने राजवंशी भाषा मोरङ र कापा जिल्लामा राजवंशी जातिले बोल्ने गर्दछ् । यस भाषालाई ताजपुरी भाषा पनि भनिन्छ। यस भाषाको उत्पत्ति थलो आसाम क्षेत्र र उत्तर-पूर्वी बड्ग्गाल हो (गौतम र चौलागाई, २०७०, पृ. ३७३)। यो भाषामा साहित्य सिर्जना भएको छैन ।

\section{हिन्दी भाषा}

वि.सं. २०६६ को जनगणना अनुसार ०.३ प्रतिशत जनसंख्याले नेपालमा मातृभाषाको रूपमा हिन्दी भाषाको प्रयोग गर्दछन्। यो भाषा भारतको राष्ट्रभाषा हो भने दक्षिण एशियाकै प्रभावशाली भाषाका रूपमा चिनिन्छ। यो भाषा मुख्य रूपमा नेपालको तराईका जिल्लाहरूमा बोलिने गर्दछ भने अन्य शहरहरूमा आएका व्यापारीहरूले पनि हिन्दी भाषाको प्रयोग गर्ने गरेको पाइन्छ। हिन्दी भाषा साहित्य सिर्जनाका दृष्टिले समृद्ध भाषाको रूपमा चिनिन्छ।

\section{दनुवारी भाषा}

दनुवार जातिले बोल्ने भएकाले यस भाषालाई दनुवारी भाषा भनिन्छ। नेपालको सिन्धुली, सर्लाही, रौतहट, उदयपुर, भापा, मोरड, काभ्षे आदि जिल्लाको भित्री मधेस र तिनका छेउछाउमा बसोबास गर्ने दनुवारहरूले यस भाषाको प्रयोग गर्दछन् (शर्मा र लुइटेल, २०६०, पृ.३०७)। लेख्य रूप नभएको दनुवारी भाषा अन्य भाषाहरूसँगको प्रभावका कारणले प्रशस्त विविधता पाइन्छ। वि.सं. २०६६ को जनगणना अनुसार ०.२ प्रतिशत जनसंख्याले नेपालमा मातृभाषाको रूपमा दनुवारी भाषाको प्रयोग गर्दछन्। 


\section{माभी भाषा}

नेपालका ठूला नदीका किनारहरूमा बसोबास गर्ने र डुड़ा तार्ने, माछा मार्ने जातिलाई माभी भनिन्छ, भने उनीहरूले बोल्ने भाषा नै माभी हो। यस भाषाको लिखित साहित्य विकास भएको छैन। कतिपय भाषाशास्त्रीहरूले माभी र बोटे एउटै भाषा हुन् भन्ने मान्यता राखेको पाइन्छ, किनभने बोटे भनिनेहरूले नै माभी लेख्ने गरेको पाइन्छ। नेपालमा वि.सं. २०६६ को जनगणना अनुसार ०.०६ प्रतिशत जनसंख्याले यस भाषालाई मातृभाषाको रूपमा बोल्ने गर्दछ् ।

\section{दरै भाषा}

दरै जातिको बसोबास भएका नेपालका जिल्लाहरू चितवन, पाल्पा, तनहुँ आदिमा दरै भाषा बोलिन्छ, यस भाषामा कुनै पनि लिखित साहित्य छैन। अन्य भाषाहरूको प्रभावमा परेर दरै भाषामा पनि प्रशस्त विविधता आएको छ। २०६६ को जनगणना अनुसार नेपालमा ०.०१ प्रतिशत जनसंख्याले मातृभाषाको रूपमा यो भाषा बोल्ने गर्दछन्।

\section{कुमाल भाषा}

कुमाले भाषा अर्धमागधी प्राकृतबाट विकसित भाषा हो (गौतम र चौलागाई, २०७०, पृ. ३७५) ।माटाका भाँडा बनाउने जाति कुमालहरूले बोल्ने भाषालाई कुमालले भाषा भनिन्छ। कुमाले भाषाका वक्ताहरू नेपालका स्याङ्जा, पाल्पा, नवलपरासी, पर्वत आदि जिल्लाहरूमा बसोबास गर्दछन्। नेपाली लगायत अन्य भाषाको प्रभावमा परेर लोपोन्मुख अवस्थामा रहेको कुमाले भाषाको प्रयोग गर्नेहरूको संख्या ०.०४ प्रतिशत वि.सं. २०६६ को जनगणनाले देखाएको छ।

\section{चुरेटी भाषा}

नेपालका पहाडी जिल्लाहरूमा चुरापोतेको व्यापार गर्ने घुमन्ते व्यापारीहरूलाई चुरेटा भनिन्छ। उनीहरूले प्रयोग गर्ने भाषा नै चुरेटी हो। यस भाषाको लिखित रूप र लिपि छैन। २०६६ को जनगणना अनुसार नेपालमा यो भाषा प्रयोगकर्ताको सड्ख्या १०७४ जना मात्र रहेको छ।

\section{बंगाली भाषा}

बड्गाली भाषा संस्कृतको मागधी प्राकृत र मागधी अपभंश्रंशाट विकसित भएको हो (गौतम र चौलागाई, २०७०, पृ. ३७५ ) । भारतको पश्चिम बंगाल र बंगलादेशको प्रमुख भाषा बंगाली नेपालका भापा र मोरड जिल्लामा बोलिन्छ। यो अत्यन्त सम्पन्न साहित्य भएको भाषा हो। यो भाषा कुटिला लिपिमा लेखिन्छ। यसै भाषाका कवि रवीन्द्रनाथ ठाकुर साहित्यमा नोबेल पुरस्कार प्राप्त गर्ने पहिलो भारतीय नागरिक हुन्। नेपाली भाषाको पनि यस भाषासँग गहिरो सम्बन्ध रहेको छ। २०६६ को जनगणना अनुसार नेपालमा यो भाषा प्रयोगकर्ता ०.०७ प्रतिशत रहेका छन् ।

\section{मारवाडी भाषा}

भारतको राजस्थान पश्चिम क्षेत्रबाट नेपाल आएका मारवाडीहरूले बोल्ने भाषा नै मारवाडी भाषा हो । व्यापारको सिलसिलामा नेपाल आएकाहरूले नेपालमा पनि यस भाषालाई स्थापित गरेका छन्। नेपालका प्रमुख उद्योगी र व्यापारीहरू मारवाडी नै छन्, उनीहरूले नै यस भाषाको प्रयोग गर्दछन्। नागरिक लिपिमा 
नेपालमा बोलिने भाषाहर्क्को परिचय/223

लेखिने यस भाषाको आफ्नै लिपि र साहित्य पनि छ। २०६६ को जनगणना अनुसार नेपालमा ०.१ प्रतिशत जनसंख्या मातृभाषाको रूपमा मारवाडी प्रयोग गर्ने रहेको छ।

उपर्युक्त भाषाहरूका साथै मगही र अंग्रेजी भाषा पनि भारोपेली भाषापरिवार अन्तर्गतका भाषाहरू हुन् । अत्यन्त न्यून जनसंख्या मानिएको मगही भाषा हिन्दी भाषाको भेद मानिन्छ भने अंग्रेजी भाषा अन्तर्राष्ट्रिय भाषाको मान्यता पाएको र प्राथमिक तहदेखि उच्च तहसम्म शिक्षाको माध्यम मानिएको भाषा हो। यस भाषाका पनि नेपालमा मातृभाषी जनसंख्या भएको मानिन्छ, तर संख्यामा भने न्यूनता नै छ।

\section{ख) भोटबर्मेली भाषापरिवार}

यस भाषा परिवारलाई चिनियाँ तिब्बती भाषा परिवार पनि भनिन्छ । नेपालमा भारोपेली भाषापरिवार पछिको धेरै जनसंख्या यसै भाषापरिवारमा छ। भाषा संख्याका दृष्टिले भने भारोपेली भाषापरिवारका भन्दा पनि बढी भाषाहरू यस भाषापरिवारका छ, । यस भाषापरिवारका वक्ताहरू चीन, तिब्बत, बर्मा, नेपाल, भारत, भुटान, बंगलादेश, थाइल्यान्ड, भियतनाम आदि देशहरूमा बोलिन्छ। यस भाषा परिवारका तामाड, नेवारी, मगर, राई, थकाली, जिरेल, मेचे, सुनुवारी, हायु, ब्याँसो राउटे, पहरी, लेच्चा, दूरा, राजी, कागते आदि भाषाहरू नेपालमा बोलिन्छन् । तामाङ यस परिवारको सबभन्दा बढी जनसड्ख्याले बोल्ने भाषा हो (बन्धु, २०७३, प्. २१३)। यस भाषापरिवारका प्रमुख भाषाहरूको संक्षिप्त चिनारी यहाँ प्रस्तुत गरिएको छ।

तालिका ३ : नेपालमा बोलिने भोटबर्मेली परिवारका भाषाहरूको तुलना २०४६ र २०६६

\begin{tabular}{|c|c|c|c|c|c|c|c|}
\hline $\begin{array}{l}\text { क. } \\
\text { सं }\end{array}$ & $\begin{array}{l}\text { भाषा } \\
\text { परिवार }\end{array}$ & \multicolumn{3}{|c|}{ राष्ट्रिय जनगणना २०४६ } & \multicolumn{3}{|c|}{ राष्ट्रिय जनगणना २०६६ } \\
\hline & भोटबर्मेली & भाषा & $\begin{array}{l}\text { वक्ता } \\
\text { प्रतिशत }\end{array}$ & वक्ता सड्ख्या & भाषा & $\begin{array}{l}\text { वक्ता } \\
\text { प्रतिशत }\end{array}$ & वक्ता सड्ख्या \\
\hline 9. & & तामाङ & 2.99 & १৭७९१४४ & तामाङ & 4.99 & १३५ ३३१९ \\
\hline २. & & नेवार & ३.६३ & Б२૫ชУ & नेवार & ३. २० & 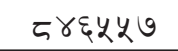 \\
\hline ३. & & मगर & ३.९३ & ७७০৭৭६ & मगर & र. . 9 & ৩૬こप३३० \\
\hline$\gamma$. & & लिम्बु & $9.8 ৩$ & ३३३६३३ & लिम्बु & १.३० & ३૪३६०३ \\
\hline$y$. & & गुरुड & 9.89 & ३३५९२૫ & गुरुङ & १.२३ & ३२Ч६६२२ \\
\hline$\xi$. & & राई & - & - & राई & $0 . \xi 0$ & 949998 \\
\hline$\vartheta$ & & बान्तवा & $9 . \xi ३$ & ३७१०૫ૂ६ & बान्तवा & 0.40 & १३२У Б३ \\
\hline$\zeta$. & & शेर्पा & 0.20 & ৭२९७७१ & शेर्पा & O. ४३ & ৭৭૪๘३০ \\
\hline$\rho$. & & चाम्लिड & 0.20 & ४૪০९३ & चाम्लिड & 0.29 & ७६५०० \\
\hline 90. & & चेपाड & $0.9 \xi$ & ३६५०७ & चेपाड & 0.95 & ૪ち૪३६ \\
\hline 99. & & सुनुवार & 0.92 & २६६११ & सुनुवार & 0.98 & ३७५९ Б \\
\hline १२. & & कुलुड & 0.05 & १६६ऽ६ & कुलुड & $0.9 ३$ & ३३१७০ \\
\hline १३. & & खाम (मगर) & - & - & खाम (मगर) & 0.90 & २७११३ \\
\hline 98. & & थाड़मी & 0.05 & १६९९१ & थाड़मी & 0.09 & २३१४१ \\
\hline
\end{tabular}




\begin{tabular}{|c|c|c|c|c|c|c|}
\hline 94. & भुजेल & $0.0 y$ & १०७३३ & भुजेल & 0.05 & २१७१७ \\
\hline $9 \xi$. & थुलुड & 0.04 & ৭४০३૪ & थुलुड & 0.05 & २०६प९ \\
\hline$q ७$. & याक्खा & $0.0 \xi$ & १४६૪๘ & याक्खा & $0.0 ७$ & $99 y 25$ \\
\hline 95. & धिमाल & 0.05 & १७३০૬ & धिमाल & 0.06 & १९३०० \\
\hline 99. & साम्पाड & $0.0 y$ & 90590 & साम्पाड & 0.06 & १૬২७০ \\
\hline २०. & खालिड & O.०३ & ९२Бム & खालिड & 0.04 & ৭૪૪६৩ \\
\hline २१. & वाम्बुले & 0.02 & ૪૪७৭ & वाम्बुले & 0.04 & ৭३૪৩০ \\
\hline २२. & बाहिड & 0.09 & २७६ू & बाहिड & 0.08 & ११६४ द \\
\hline २३. & यहोल्मो & 0.02 & ३९ॅ६ & चहोल्मो & 0.08 & ৭०৭६७ \\
\hline २४. & नाछेरिड & 0.02 & 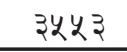 & नाछेरिड & 0.08 & 90089 \\
\hline $2 y$. & याम्फु & 0.09 & १७२२ & याम्फु & $0.0 ३$ & 9905 \\
\hline २६. & घले & 0.09 & १६४९ & घले & O.०३ & Б०९२ \\
\hline २७. & दुमी & 0.02 & प २७१ & दुमी & O.०३ & ७६३५ \\
\hline २५. & लाप्चा & 0.09 & २६२६ & लाप्चा & $0.0 ३$ & ७४९९ \\
\hline 29. & पुमा & 0.02 & ૪३१० & पुमा & O.०३ & ६६ॅ६ \\
\hline ३०. & दुड्माली & 0.00 & २२१ & दुड्माली & 0.02 & ६२६० \\
\hline ३१. & आठपरिया & - & - & आठपरिया & 0.02 & қy \\
\hline ३२. & थकाली & $0.0 ३$ & $\xi ૪ ૪ १$ & थकाली & 0.02 & पूर२ \\
\hline ३३. & जिरेल & 0.02 & ४९9९ & जिरेल & 0.02 & ४५२९ \\
\hline ३૪. & मेवाहाङ & 0.00 & ९०४ & मेवाहाङ & 0.02 & ૪६yo \\
\hline ३५. & तिब्बती & 0.02 & पू२७७ & तिब्बती & 0.02 & $\gamma \gamma \gamma y$ \\
\hline ३६. & मेचे & 0.09 & ३३०१ & मेचे & 0.02 & ૪३७૫ \\
\hline ३७. & छन्त्याल & O.०३ & प९9२ & छन्त्याल & 0.02 & ૪२६३ \\
\hline ३६. & राजी & 0.09 & २४१३ & राजी & 0.09 & ३७४ ६ \\
\hline ३९. & लोहोरुड & 0.09 & १२०७ & लोहोरुड & 0.09 & ३७१६ \\
\hline ૪૦. & छिन्ताङ & 0.00 & 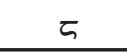 & छिन्ताड & 0.09 & ३७१२ \\
\hline 89. & पहरी & 0.09 & 2994 & पहरी & 0.09 & ३४पू \\
\hline ૪२. & ल्होपा & - & - & ल्होपा & 0.09 & ३०२९ \\
\hline ४३. & दुरा & 0.02 & ३३९७ & दुरा & 0.09 & २१४६ \\
\hline ૪૪. & कोचे & 0.00 & $y \gamma$ & कोचे & 0.09 & २०६० \\
\hline$\gamma y$. & छि,लिड & 0.09 & १३१૪ & छि,लिड & 0.09 & २०४६ \\
\hline$\gamma \xi$. & जेरो / जेरुड & 0.00 & २७१ & जेरो / जेरुङ & 0.09 & q७६३ \\
\hline 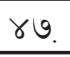 & डोल्पाली & - & - & डोल्पाली & 0.09 & १६६७ \\
\hline$\gamma \varsigma$. & हायु & 0.09 & १७४३ & हायु & 0.09 & १Y२० \\
\hline 89. & तिलुड & 0.00 & 390 & तिलुड & 0.09 & 9४२४ \\
\hline yo. & कोयी & 0.09 & २६४१ & कोयी & 0.00 & १२७१ \\
\hline 49. & वालिड & - & - & वालिड & 0.00 & $99 \xi ९$ \\
\hline
\end{tabular}


नेपालमा बोलिने भाषाहर्को परिचय/225

\begin{tabular}{|c|c|c|c|c|c|c|}
\hline पर. & ल्होमी & 0.00 & $\gamma$ & ल्होमी & 0.00 & ऽОБ \\
\hline y३. & बेलहारे & - & - & बेलहारे & 0.00 & 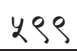 \\
\hline yr. & ब्याँसी & 0.09 & १७३४ & ब्याँसी & 0.00 & $\gamma \curvearrowleft O$ \\
\hline$y y$. & खाम्ची (राउटे) & 0.00 & पूर & खाम्ची (राउटे) & 0.00 & ૪६१ \\
\hline पू. & साम & 0.00 & २३ & साम & 0.00 & ૪०१ \\
\hline y̧o. & मनाडे & - & - & मनाडे & 0.00 & ३९२ \\
\hline$y=$. & धुलेली & - & - & धुलेली & 0.00 & ३४৩ \\
\hline yू. & फाड़्दुआली & - & - & फाङ़द्याली & 0.00 & 290 \\
\hline$\xi ०$. & सुरेल & - & - & सुरेल & 0.00 & २६७ \\
\hline$\xi १$. & चिनियाँ & 0.00 & 9909 & चिनियाँ & 0.00 & $2 \gamma 2$ \\
\hline$\xi २$. & बराम & 0.00 & ३४२ & बराम & 0.00 & $9 y 2$ \\
\hline$\xi ३$. & लिड़िम & 0.00 & $\rho \theta$ & लिड़िम & 0.00 & 929 \\
\hline$\xi \gamma$. & कागते & 0.00 & 90 & कागते & 0.00 & $\rho \rho$ \\
\hline$\xi Y$. & जोड़खा & 0.00 & $\rho$ & जोड़खा & 0.00 & ५० \\
\hline$\xi \xi$. & बनकरिया & - & - & बनकरिया & 0.00 & $\xi ९$ \\
\hline$\xi \vartheta$. & काइके & 0.00 & ७९४ & काइके & 0.00 & yo \\
\hline$\xi ち$. & मिजो & 0.00 & 5 & मिजो & 0.00 & ३२ \\
\hline$\xi ९$. & कुकी & 0.00 & $\rho$ & कुकी & 0.00 & 29 \\
\hline ৩০. & नागामी & 0.00 & $\xi$ & नागामी & 0.00 & 90 \\
\hline
\end{tabular}

स्रोत : केन्द्रीय तथ्याड़क विभाग, राष्ट्रिय जनगणना, २०४६ र २०६६

माथिको तालिका नं. ३ मा नेपालको राष्ट्रिय जनगणना २०४६ र २०६६ मा रहेका भोटबर्मेली भाषा परिवारका भाषाहरूको सड्ख्या र प्रतिशतलाई तुलनात्मक रूपमा देखाइएको छ। राष्ट्रिय जनगणना २०४६ मा $Y \zeta$ रहेकोमा राष्ट्रिय जनगणना २०६६ मा १२ वटा भाषा थपिएर ७० भएको देखिन्छ । राष्ट्रिय जनगणना २०६६ मा राई, खाम (मगर), आठपहरिया, ल्होपा, डोल्पाली, वालिड, बेलहारे, मनाडे, धुलेली, फाङ्दुआली, सुरेल र बनकरिया भाषाहरू थप भएका देखिन्छन्। भोटबर्मेली भाषा परिवारका मुख्य भाषाहरूलाई निम्न बमोजिम विश्लेषण गरिएको छ:

\section{तामाङ भाषा}

तामाङ भाषा भोटबर्मेली भाषापरिवारअन्तर्गत नेपालमा सबैभन्दा बढी जनसंख्या भएको भाषा हो। यो भाषा नेपाल भित्र र बाहिर बोलिने गर्दछ। नेपालमा मकवानपुर, नुवाकोट, रसुवा, सिन्धुपाल्चोक, काभ्रे, धादिड, रामेछाप, सिन्धुली, आदि जिल्लाहरूमा बोलिन्छ भने नेपाल बाहिर दार्जिलिड, सिक्किम, आसाम, नागालैन्ड, भुटान, बर्मा आदि ठाउँहरूमा बोलिन्छ। लेख्य साहित्यको भरखरै सुरुवात गरिएको यस भाषाले नेपालमा रेडियो, पत्रपत्रिका, आदिमा पनि प्रवेश पाएको छ भने प्राथमिक तहदखि उच्च तहसम्मको अध्ययनका लागि पनि स्वीकृत भाषा हुन पुगेको छ। यस भाषाका प्राचीन कृतिहरू तिब्बती लिपिमा लेखिएका भए पनि हिजोआज देवनागरी लिपिमा लेख्न थालेको पाइन्छ (ढकाल, २०६६, पृ. ३६४-३६४)। वि.सं. २०६६ को जनगणना अनुसार यस भाषालाई मातृभाषाको रूपमा प्रयोग गर्नेहरू नेपालमा 4.90 प्रतिशत छन्। 


\section{नेवारी भाषा}

नेवार जातिले प्रयोग गर्ने भाषालाई नेवारी भाषा भनिन्छ। यो भाषा मुख्य रूपमा काठमाडौं उपत्यकामा बोलिन्छ भने यसका साथसाथै दोलखा, काभ्रे, रामेछाप, सिन्धुली, आदि जिल्लाहरूका साथै व्यापारिक दृष्टिले अन्यत्र गई बसोबास गरेका नेवारहरू यस भाषाका वक्ता हुन् । पहिले नेवारी लिपि र क्योमोल, गोलमोल, भुँजिमोल, रज्जना, लुतिमोल आदि शैलीमा लेखिएको पाइएता पनिअहिले यस भाषामादेवनागरी लिपिको प्रयोग भएको पाइन्छ (शर्मा र लुइटेल, २०६०, पृ.३१०)। आफ्नै समृद्ध साहित्य भएको यस भाषामा पत्रपत्रिका प्रकाशन, साहित्य लेखन, फिल्म, टेलिफिल्म निर्माण र गीत गायनका कार्यहरू प्रशस्त भएको पाइन्छ। वि.सं. २०६६ को जनगणना अनुसार नेवारी भाषी प्रयोगकर्ताहरू नेपालमा ३.२० प्रतिशत छन् ।

\section{मगर भाषा}

मगर भाषा नेपालका पाल्पा, तनहुँ, नवलपरासी स्याङ्जा, उदयपुर, सिन्धुली, रोल्पा, दैलेख, सल्यान, सुर्खेत, आदि जिल्लाहरूमा बोलिन्छ। यस भाषालाई मगर ढुट र मगर खास गरी छुट्टा छुट्टै भाषाको रूपमा पनि लिने गरिन्छ। यसलाई लाड्घाली, लाखाली काइकेलीका नामले पनि पुकारेको पाइन्छ (ढकाल, २०६६, पृ. ३६दू)। मगर भाषा आख्वा लिपिमा लेखिन्छ। मगर भाषाले रेडियो नेपालमा समाचार वाचनमा प्रवेश पाएको छ भने यस भाषामा शब्दकोश, व्याकरण, पत्रपत्रिका लेखन कार्यको पनि सुरुवात भएको छ। वि.सं. २०६५ को जनगणना अनुसार यस भाषाको प्रयोग गर्ने मातृभाषीको संख्या २.९६ प्रतिशत रहेको छ।

\section{राई-किराँतीभाषा}

राई-किराँती भाषासमूहको नाम हो। यस भित्र अनेकौं थरीका राई भाषाहरू रहेका छन् । राई जातिका थरहरू अनुसार भाषाहरू पनि फरक-फरक भएको पाइन्छ। बान्तवा, चाम्लिड, खालिड, आठपहरिया, कुलुङ, थुलुङ, छुलुङ, आदि २१ थरी राई जातिको सामूहिक नाम राई-किराँती हो। यिनीहरूको भाषामा कतिपय भाषाहरू परस्पर बोधगम्य छन् भने कतिपय राई भाषा एकापसमा अबोधगम्य छन् । राई भाषाको प्रयोग क्षेत्र धनकुटा, खोटाङ, उदयपुर, भोजपुर, इलाम, संखुवासभा, रामेछाप आदि जिल्लाहरू हुन् । राई-किराँती भाषा श्रीजड़ा लिपिमा लेखिन्छ। यसलाई मातृभाषाको रूपमा बोल्नेहरूको जनसंख्या राष्ट्रिय जनगणना २०६६ अनुसार ०.६० प्रतिशत रहेको छ।

\section{लिम्बु भाषा}

लिम्बु जातिका मानिसहरूले प्रयोग गर्ने भाषा नै लिम्बु भाषा हो । यस भाषाका प्रयोगकर्ताहरू धनकुटा, पाँचथर, संखुवासभा, तेह्बथुम, ताप्लेजुङ, इलाम, सुनसरी, मोरङ, कापा आदि जिल्लाहरूमा पाइन्छन् । लोक साहित्यका दृष्टिले सम्पन्न मानिने लिम्बु भाषाको आफ्नै श्रीजड़ा वा सिरीजड्गा लिपि छ तर अहिले यो भाषा पनि देवनागरी लिपिमा लेखिन्छ। यिनीहरूको धर्म ग्रन्थ ‘मुन्धुम’ यसै लिपिमा नै लेखिएको छ (ओका, २०६७, प्. ४२७)। रेडियो नेपाल र केही एफ.एम.हरूमा यस भाषामा समाचार वाचन हुने गरेको छ। २०६६ को जनगणना अनुसार यस भाषाका प्रयोगकर्ता १.३० प्रतिशत रहेका छन् ।

\section{गुरुड भाषा}

यो गुरुु जातिले प्रयोग गर्ने भाषा हो, यसलाई तमु पनि भनिन्छ। यस भाषाभाषीको प्राचीन मूलथलो लमजुङ भएपनि मनाङ, मुस्ताङ,कास्की, तनहुँ, पर्वत, स्याङ्जा, गोर्खा आदि क्षेत्रहरूमा पनि यिनीहरूको 
बसोबास पाइन्छ (शर्मा र लुइटेल, २०६०, पृ.३११)। यो भाषा तिब्बती भाषासँग थेरै मिल्दोजुल्दो छ। गुरुु भाषा खेम तमु प्रिह लिपिमा लेखिन्छ। यस भाषामा शब्दकोश निर्माण भएको छ। पश्चिमान्चल विकास क्षेत्रमा रेडियोमा समाचार वाचन हुने गरेको यस भाषामा संस्कृतिको अध्ययन हुन थालेको छ तर साहित्यिक लेखन भने हुन सकेको छैन। २०६६ सालको जनगणना अनुसार यस भाषाका प्रयोगकर्ता १. २३ प्रतिशत रहेका छन् ।

\section{शेर्पा भाषा}

हिमाली जातिका नामले समेत चिनिने शेर्पाहरूले प्रयोग गर्ने भाषा नै शेर्पा भाषा हो । यसको मूल थलो सोलुखुम्बु जिल्ला भए पनि नेपालका हिमाली जिल्लामा बसोबास गर्ने शेर्पाहरू पनि यस भाषाका प्रयोगकर्ता हुन् । अतः यो भाषा सोलुखुम्बु लगायत हुम्ला, मनाङ, मुस्ताङ, रामेछाप, दोलखा, आदि जिल्लाहरूमा बोलिन्छ। यस भाषाको तिब्बती भाषासँग नजिकको सम्ब्ध रहेको छ। वि.सं. २०६६ को जनगणना अनुसार यस भाषालाई मातृभाषाको रूपमा प्रयोग गर्नेहरू ०. ४३ प्रतिशत रहेका छन् ।

\section{धिमाल भाषा}

यो धिमाल जातिले बोल्ने भाषा हो। कापा, मोरड र सुनसरीका विभिन्न ठाउँगाउँमा यिनीहरूको बसोबास छ (ढकाल, २०६६, पृ. ३६६)। यो भाषा कथ्य स्तरमा नै सीमित छ। भारतका विभिन्न ठाउँहरूमा समेत बोलिने धिमाल भाषालाई मातृभाषाको रूपमा बोल्नेहरू जनगणना २०६६ अनुसार ०.०७ प्रतिशत मात्र रहेका छन् ।

\section{थकाली भाषा}

थकाली भाषाको मूल थलो मुस्ताङ जिल्लाको थाकखोला हो । यसका साथै यस भाषाका वक्ताहरू स्याङ्जा, कास्की लगायतका जिल्लाहरूमा पनि पाइन्छन्। थकाली भाषा पनि मौखिक स्तरमा सीमित भाषा हो । २०६६ को जनगणना अनुसार यस भाषाका प्रयोगकर्ता ०.०२ प्रतिशत मात्र रहेका छन्।

\section{जिरेल भाषा}

दोलखा जिल्लाको जिरी र त्यसको आसपासमा बसोबास गर्ने जातिलाई जिरेल भनिन्छ। जिरेलहरूले यस भाषालाई मातृभाषाको रूपमा बोल्ने गई्छन्। यो दोलखाका साथै चितवन, पर्सा र बारामा पनि बोलिन्छ। यो भाषा पनि कथ्य स्तरमै सीमित रहेको छ। २०६६ को जनगणना अनुसार यो भाषा बोल्ने वक्ताको सड्ख्या ०.०२ प्रतिशत रहेको छ।

\section{दुरा भाषा}

लम्जुङको दुराडाँडा पैतृक थलो भएका दुराजातिको मातृभाषा दुरा हो (ढकाल, २०६६, पृ. ३६७)। कथ्य स्तरमै सीमित यो भाषा लोपोन्मुख अवस्थामा छ। यसका मातृभाषी प्रयोगकर्ता तनहुँ, कास्की चितवन जिल्लामा पनि पाइन्छन् । यसको मातृभाषी संख्या जनगणना २०६६ अनुसार ०.०१ प्रतिशत रहेका छन्।

\section{सुनुवार भाषा}

रामेछाप, सिन्धुली, ओखलढुड़ा आदि जिल्लाका सुनुवार जातिले बोल्ने भाषा नै सुनुवार भाषा हो। यो भाषा पनि कथ्य स्तरमै सीमित छ। यसको मातृभाषी संख्या जनगणना २०६६ अनुसार ०.१४ प्रतिशत रहेका छन् । 


\section{मेचे भाषा}

यस भाषाको मूल थलो कापा जिल्ला हो । मेचेलाई बोडो वा बोडे पनि भनिएको पाईन्छ (गौतम र चौलागाई, २०७०, पृ. ३६१)। यसलाई मातृभाषाका रूपमा बोल्नेको संख्या २०६६ को जनगणना अनुसार ०.०२ प्रतिशत रहेका छन् ।

उपर्युक्त भाषाहरू लगायत नेपालमा तिब्बती, लेच्चा, पहरी, ब्याँसी, कागते, राजी, मनाड्गे, कामी, राउटे, चेपाङ आदि भाषाहरू यस भाषापरिवार अन्तर्गत बोलिन्छन्। यी भाषाहरूको प्रयोगकर्ता न्यून मात्रामा छन् भने अन्य भाषाको प्रभावमा परेर लोपोन्मुख अवस्थामा पुगेका छन् ।

\section{ग) आग्नेली भाषा परिवार}

नेपालको पूर्वी तराइको भापा जिल्लामा र सीमावर्ती भारतको बिहार, बड़गाल र आसाम राज्यमा फैलिएका सन्थालहरूको भाषा सन्थाल हो (बन्धु, २०७३, प्. २१०)। भारतमा सन्थाल भाषाभाषीको सड्ख्या बढ़ी भएकाले त्यहाँ यस भाषाका पाठ्यसामग्री देवनागरी र रोमन लिपिमा उपलब्ध छन् । यिनीहरूको ओलचिकी भन्ने लिपि पनि छ (ऐजन पृ. २१९)।

\section{तालिका $४$ : नेपालमा बोलिने आग्नेसियाली परिवारका भाषाहरूको तुलना २०४६ र २०६६}

\begin{tabular}{|c|c|c|c|c|c|c|c|}
\hline क.सं & भाषा परिवार & \multicolumn{3}{|c|}{ राष्ट्रिय जनगणना २०४६ } & \multicolumn{3}{|c|}{ राष्ट्रिय जनगणना २०६६ } \\
\hline & आग्नेसियाली & भाषा & वक्ता प्रतिशत & $\begin{array}{l}\text { वक्ता } \\
\text { सड़ख्या }\end{array}$ & भाषा & $\begin{array}{l}\text { वक्ता } \\
\text { प्रतिशत }\end{array}$ & वक्ता सड्ख्या \\
\hline 9 . & & सन्थाली & 0.95 & ૪০२६० & सन्थाली & 0.99 & ४९รप९ \\
\hline २. & & खरिया & 0.09 & qy৩y & खरिया & 0.00 & २३५ \\
\hline
\end{tabular}

स्रोत : केन्द्रीय तथ्याड़क विभाग, राष्ट्रिय जनगणना, २०६६ र २०६५

नेपालमा आग्नेली भाषापरिवार अन्तर्गत सतार वा सन्थाल र खडिया भाषा मात्र बोलिन्छ क्य स्तरमै सीमित सन्थाली भाषा नेपालका मोरङ र भापा जिल्लामा बोलिन्छ। २०४६ को जनगणनामा यस भाषालाई सतार र सन्थाल गरी छुट्टाछुट्टै नामकरण गरिए पनि वास्तवमा सतार जातिले प्रयोग गर्ने भाषा नै सतार भाषा हो। यसलाई सन्थाल पनि भनिन्छ। यस भाषाका प्रयोगकर्ता ०.१९ प्रतिशत मात्र रहेको २०६६ को जनगणना तथ्याङ्कले देखाउँछ। खडिया भाषाको प्रयोग भापा, मोरड र कपिलवस्तुमा गरिन्छ। यो अलिखित भाषा हो र यसको प्रयोग मौखिक परम्परामा मात्रै हुँदै आएको छ (ओभा, २०६७, पृ. ४३०)। वि.सं. २०६६ को राष्ट्रिय जनगणना अनुसार यस भाषा बोल्ने वक्ता २३६ जना रहेको देखिन्छ।

\section{घ) द्रविड भाषापरिवार}

पूर्वी तराईको मोरङद्देखि पर्सासम्म छरिएर बसेका द्रविड मूलका उराँवहरूले बोल्ने भाषालाई धाँगड वा भाँगड भाषा भनिएको छ भने अहिले उराँव भनिएको छ। भारतको छोटा नग्गपुरमा बोलिने कुरुख भाषासँग यसको साम्य छ भन्ने विद्वान्हरूूको भनाइ छ। (बन्धु, २०७३, पृ. २११)। 
नेपालमा बोलिने भाषाहर्को परिचय/229

तालिका $y$ : नेपालमा बोलिने द्रविड परिवारका भाषाहरूको तुलना २०४६ र २०६६

\begin{tabular}{|c|c|c|c|c|c|c|c|}
\hline ऋ.सं. & भाषा परिवार & \multicolumn{3}{|c|}{ राष्ट्रिय जनगणना २०४६ } & \multicolumn{3}{|c|}{ राष्ट्रिय जनगणना २०६६ } \\
\hline & द्रविड & भाषा & $\begin{array}{l}\text { वक्ता } \\
\text { प्रतिशत }\end{array}$ & $\begin{array}{l}\text { वक्ता } \\
\text { सड़ख्या }\end{array}$ & भाषा & $\begin{array}{l}\text { वक्ता } \\
\text { प्रतिशत }\end{array}$ & वक्ता सड्ख्या \\
\hline q. & & भाँगड / धाँगर & $0.9 ३$ & २६६१४ & उराँव & $0.9 ३$ & ३३६४ १ \\
\hline
\end{tabular}

स्रोत : केन्द्रीय तथ्याड़क विभाग, राष्ट्रिय जनगणना, २०४६ र २०६६

द्रविड भाषापरिवार अन्तर्गत पर्ने भाँगड वा धाँगड भाषा मात्र नेपालमा बोलिन्छ। नेपालको पूर्वी तराईका जिल्ला भापा, मोरङ, सिराहा र जनकपुर जिल्लामा यस भाषाका वक्ता पाइन्छन् । २०६६ को जनगणना अनुसार भाँगड भाषालाई मातृभाषाको रूपमा बोल्ने वक्ता $० . १ ३$ प्रतिशत मात्र रहेका छन् ।

\section{ङ) एकल भाषापरिवार}

अन्य भाषा परिवारसाग नमिल्ने भाषालाई यस अन्तरगत राखिन्छ। नेपालमा यस भाषा परिवार अन्तरगत कुसुन्डा भाषा पर्दछ ।

तालिका ६ : नेपालमा बोलिने एकल परिवारका भाषाहरूको तुलना २०४६ र २०६६

\begin{tabular}{|c|c|c|c|c|c|c|c|}
\hline क.सं. & भाषा परिवार & \multicolumn{3}{|c|}{ राष्ट्रिय जनगणना २०४६ } & \multicolumn{3}{|c|}{ राष्ट्रिय जनगणना २०६ } \\
\hline & एकल भाषा & भाषा & $\begin{array}{c}\text { वक्ता } \\
\text { प्रतिशत }\end{array}$ & वक्ता सड्ख्या & भाषा & वक्ता प्रतिशत & $\begin{array}{c}\text { वक्ता } \\
\text { सड्ख्या }\end{array}$ \\
\hline १. & & कुसुन्डा & 0.00 & $\zeta ७$ & कुसुन्डा & 0.00 & २५ \\
\hline
\end{tabular}

स्रोत : केन्द्रीय तथ्याड्क विभाग, राष्ट्रिय जनगणना, २०४६ र २०६६

नेपालको गण्डकी क्षेत्रदेखि कर्णालीका किनारसम्म फैलेको चुरे पहाडका वरिपरि घना जड्गलमा कन्दमूल सड्कलन गर्ने र सिकारीको जीविका लिई वनमा आश्रित हुने कुसुन्डाहरूको भाषा कुसुन्डा हो (बन्धु, २०७३, पृ. २११)। वि.सं. २०६६ को राष्ट्रिय जनगणना अनुसार यस भाषा बोल्ने वक्ता २६ जना मात्र रहेको देखिन्छ।

\section{निष्कर्ष}

नेपालमा वि.सं. १९६६ सालबाट जनगणना सुरु भएको हो। नेपालमा भएका जनगणनाका तथ्याङ्क अनुसार वि.सं. २००९/११ मा ४४, वि.सं. २०१६ मा ३६, वि.सं. २०२६ मा १७,वि.सं. २०३६ मा १६,वि.सं. २०४६ मा ३१, वि.सं. २०५ द मा ९२ रवि.सं. २०६६ मा १२३ संख्यामा भाषाहरू बोल्ने गरिएको देखिन्छ। यसरी विभिन्न जनगणनामा फरक फरक भाषिक तथ्याङ्क आउनुमा वैज्ञानिक रूपमा भाषिक सर्वेक्षण नहुनु, स्पष्ट आधार विना नै विभिन्न भाषाका भाषिकाहरूलाई भाषाको मान्यता दिनु, भाषाको महत्त्वलाई ख्याल नगर्नु, आग्रह-पूर्वाग्रहका आधारमा भाषा सड्ख्या र तिनका वक्ता सड्ख्या तोक्नु आदि रहेका छन् ।यसरी यस लेखमावि.सं. २०४६ रवि.सं. २०६६ को राष्ट्रिय जनगणनाअनुसार नेपालमा बोलिने भारोपेली, भोट-बर्मेली, आग्नेली, द्रबिड गरीचार वटा भाषा परिवार र एक वटा एकल परिवार गरी पाँच वटा भाषा परिवारको तुलनात्मक अध्ययन रवि.सं. २०६६ का भाषाहरूको विश्लेषणात्मक अध्ययन गरिएको छ। 
नेपालमा बोलिने भाषा परिवार अन्तरगत वि.सं. २०४६ को ९२ रवि.सं. २०६६ को १२३ वटा भाषा मध्ये वक्ता संख्याका आधारमा जम्मा ३० वटा भाषका बारेमाविश्लेषणात्मक अध्ययन गरिएको छ।

यसबाट नेपालमा बोलिने भाषाहरूमा दश वर्षमा देखिएको परिनर्तनको अवस्था स्पष्ट हुन्छ। अब नेपालमा वि.सं. २०७६ सालमा बाह्नौं जनगणना हुँदै छ, त्यो जनगणनामा भाषिक जनगणनालाई व्यवस्थित गर्नुपर्ने कुरालाई पानि यस लेखले सङ्केत गरेको छ। भाषासम्बन्धी सरोकार राख्ने सरोकारवालालाई यस कुराप्रति गम्भीर हुन यस लेखले ध्यानाकर्षण गरेको छ।

नेपालमा बोलिने एकल भाषा परिवारसहित पाँच भाषा परिवारका वक्ताहरू छन्। ती भाषिक वक्ताहरूको अवस्थाका बारेमा रेगमी (२०१७ इ.) ले नेपालको भाषाहरूको जीवन्तताको स्थिति शीर्षकमा सुरक्षित भाषा पू३ वटा, संकटापन्न भाषा पू वटा, अपसरणशील भाषा ११ वटा, मृतप्राय भाषा ६ वटा, सुषुप्त भाषा १ वटा र लोप भएको भाषा 9 वटा रहेको कुरा उल्लेख गरेका छन्। अबको जनगणनामा राज्यले विस्तृत भाषिक विवरणका आधारमा केन्द्रीय, प्रदेश स्तरीय र स्थानीय स्तरमा भाषा योजना बनाउनु पर्दछ। त्यसको निष्कर्षलाई जनगणनाको प्रक्रियामा समावेश गर्नु उपयुक्त देखिन्छ र भाषाहरूको जीवन्तताको अवस्था हेरी उचित पहिचान, संरक्षण, संबर्धन, विकास र विस्तारका उपायहरू अवलम्बन गर्नु अत्यावश्यक देखिन्छ।

\section{सन्दर्भसूची}

अधिकारी, सूर्यमणि (२०६४), नेपाली भाषाको इतिहास, काठमाडौं : भुँडी पुराण प्रकाशन । ओका, रामनाथ (२०६७), सामान्य भाषाविज्ञान, काठमाडौं : वाङ्मय प्रकाशन गृह । केन्द्रीय तथ्याङ्क विभाग (२०६९), नेपालको राष्ट्रिय जनगणना २०६६, काठमाडौं : नेपाल सरकार । केन्द्रीय तथ्याङ्क विभाग (२०४९), नेपालको राष्ट्रिय जनगणना २०४६, काठमाडौं : नेपाल सरकार । गौतम, देवीप्रसाद र चौलागाइ, प्रेमप्रसाद (२०७०) (दोस्रो सं.), भाषाविज्ञान, काठमाडौं : पाठ्य सामग्री पसल । ढकाल, शान्तिप्रसाद (२०६६) (चौथो सं.), सामान्य भाषविज्ञान, काठमाडौं : शुभकामना प्रकाशन । तिवारी, भोलानाथ (२०४७), भाषाविज्ञान, इलाहावाद : किताब महल । पोखरेल, बालकृष्ण (२०५५), राष्ट्रभाषा (दो.सं.), ललितपुर : साका प्रकाशन । बन्धु, चूडामणि (२०७३), भाषाविज्ञान (नवौं सं.), ललितपुर : साका प्रकाशन । रेगमी, दानराज (सन् २०१७), नेपालमा भाषाहरूको स्थिति र भाषिक सर्वेक्षण : समीक्षात्मक विश्लेषण, गिपान, अड्क ३-२, काठमाडौं : भाषाविज्ञान केन्द्रीय विभाग ।

शर्मा, मोहनराज र लुइटेल, खगेन्द्रप्रसाद (२०६०), आधुनिक भाषाविज्ञान, काठमाडौं : विद्यार्थी पुस्तक भण्डार । Yada, Y. P, and Grove, C. (Eds., 2008). Report of the national language policy commission (English translation). Kathmandu: Central Department of linguistics, Tribhuvan University. 